Cahiers $d u$ MONDE RUSSE

\section{Cahiers du monde russe}

Russie - Empire russe - Union soviétique et États indépendants

40/1-2 | 1999

Archives et nouvelles sources de l'histoire soviétique, une réévaluation

\title{
Detective work
}

Researching Soviet World War II policy on Poland in Russian archives (Moscow, 1994)

\section{Anna M. Cienciala}

\section{(2) OpenEdition}

1 Journals

Electronic version

URL: http://journals.openedition.org/monderusse/13

DOI: $10.4000 /$ monderusse. 13

ISSN: $1777-5388$

Publisher

Éditions de l'EHESS

\section{Printed version}

Date of publication: 1 January 1999

Number of pages: $251-270$

ISBN: 2-7132-1314-2

ISSN: $1252-6576$

Electronic reference

Anna M. Cienciala, « Detective work », Cahiers du monde russe [Online], 40/1-2 | 1999, Online since 15 January 2007, Connection on 21 April 2019. URL : http://journals.openedition.org/monderusse/13 ; DOI : 10.4000/monderusse.13 


\section{DETECTIVE WORK: RESEARCHING SOVIET WORLD WAR II POLICY ON POLAND IN RUSSIAN ARCHIVES (Moscow, 1994)*}

Soviet POLICY ON PolAnd during the Second World War has been, with a few exceptions, generally marginalized in English language studies of wartime diplomacy. This seems strange, for the borders and political system of postwar Poland were among Stalin's major concerns. Indeed, Soviet control of Poland would ensure Soviet control of Central and Eastern Europe as well as a land bridge to Germany. As it happened, Stalin's demands regarding Poland were a thorny issue in Anglo-Soviet relations, and sometimes a delicate one in U.S.- Soviet relations. Polish language studies on the policies of the Polish government-in-exile, its relations with Moscow, and on Polish communists, as well as specialized English language works on these subjects - including mine - were based on available Polish, British, and American sources but suffered from the lack of Russian archival material. This, of course, allowed - and still allows - for different interpretations of Soviet policy towards Poland, and of Soviet wartime policy in general. ${ }^{1}$

* This is a revised version of the paper I read at the seminar on "Assessing the new Soviet archival sources,” Yale University, New Haven, CT, May 17, 1997.

1. English language studies that give some coverage to the Polish question include: Martin Kitchen, British policy towards the Soviet Union during the Second World War (New York, 1986); Steven M. Miner, Between Churchill and Stalin. The Soviet Union and the origins of the grand alliance (Chapel Hill — London, 1988). Of those that deal specifically with Poland, the most important are: Detlef Brandes, Grossbritanien und seine osteuropäischen Allierten, 19391943 (Munich, 1988) (the sections on Poland are based on British and Polish archival sources); John Coutovidis, Jaime Reynolds, Poland 1939-1947 (Leicester — New York, 1986) (based mainly on British archival documents); George Kacewicz, Great Britain, the Soviet Union and the Polish government in exile 1939-1945 (The Hague, 1979) (based mostly on published sources); Jan Karski, The Great Powers and Poland 1919-1945. From Versailles to Yalta (Lanham - New York - London, 1985) (based mostly on published sources); Richard C. Lukas, The strange allies. The United States and Poland 1941-1945 (Knoxville, TN, 1978) (based on U.S. and Polish archival sources); Anita J. Praßmowska, Britain and Poland 1939- 
Some years ago, I completed research on the topic: "Poland in British, U.S. and Soviet policies in World War II," at the British Public Record Office, in the National Archives, Washington, DC, and the Franklin D. Roosevelt Library, Hyde Park, NY, also in Polish government collections located at the Hoover Archives, Stanford, CA, and at the Polish Institute and Sikorski Museum, London. In Warsaw, I had read the press and radio materials of the Polska Partia Robotnicza (PPR, Polish Workers' Party), as well as some files of the Zwiàzek Patriotów Polskich w ZSSR (ZPP, Union of Polish Patriots in the USSR). These carefully selected files were the only archival sources accessible to non-party historians before 1989. In 1993, I read PPR documents, formerly in the closed Central Committee Archives, transferred after the fall of communism to the Archiwum Akt Nowych (AAN, Polish State Archives on Modern History), Warsaw. My articles on Polish-Soviet relations and the Polish question in World War II were, with one exception, based on archival documents available in the West, plus published sources. ${ }^{2}$ These articles were to serve as chapters for my book on Poland in British, U.S. and Soviet policy in World War II, due for completion in 1989-1990. However, on the collapse of communism, I decided to wait until I could read Russian archival documents. Finally, in summer 1994, with the aid of a short term IREX grant, I was able to undertake research in Moscow.

Before discussing my research in Moscow archives, I will give a brief outline of what was, until recently, already known about Soviet policy on Poland in World War II but is not generally known today except to specialists on the subject. Next, I will enumerate documents published since 1992 — when some important Russian documents were published — giving examples mainly from the period 1939-1941,

1943. The betrayed ally (Cambridge, 1995) (based on British and Polish archival sources but flawed by the author's unremitting condemnation of the Polish government-in-exile); Sarah Meiklejohn Terry, Poland's place in Europe. General Sikorski and the origin of the OderNeisse line, 1939-1943 (Princeton, NJ, 1983) (based on British and Polish archival sources). For a study of the Polish communists in the period 1943-1948, see: Krystyna Kersten, The establishment of communist rule in Poland, 1943-1948 (Berkeley, CA, 1991) (based mainly on PPR archival sources). Polish language studies on Polish-Soviet relations in World War II have thus far been based mostly on Polish archival sources, see: Jacek Sfusarczyk, Stosunki polskosowieckie 1939-1945 (Warsaw, 1993) and Eugeniusz Duraczyn\&ki, "Polska w polityce

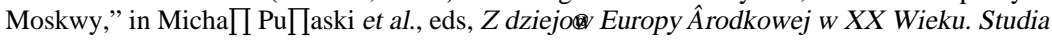
ofiarowane Henrykowi Batowskiemu w 90 rocznic' urodzin (Krako@, 1997): 171-184. The one Russian language monograph on Polish-Soviet wartime relations: Valentina S. Parsadanova, Sovetsko-pol'skie otnosheniia v gody Velikoi Otechestvennoi voiny (Moscow, 1982 ) is based on then available sources and reflects the official Soviet view at the time.

2. See: Anna M. Cienciala, "The question of the Polish-Soviet frontier in 1939-1940," Polish Review, 33, 3 (New York, 1988): 295-324; Id., "The diplomatic background of the Warsaw Rising of 1944: The players and the stakes," ibid., 39, 4 (1994): 393-413; Id., "Great Britain and Poland before and after Yalta, 1943-1945," ibid., 40, 3 (1995): 281-314; Id., "General Sikorski and the conclusion of the Polish-Soviet agreement of July 30, 1941: A reassessment," ibid., 41, 4 (1996): 401-434; Id., "New light on Oskar Lange as an intermediary between Roosevelt and Stalin in attempts to create a new Polish government (January-November 1944)," Acta Poloniae Historica, 73 (Warsaw, 1996): 89-134 (based mainly on O. Lange papers in the Arkhiv Vneshnei Politiki Rossiiskoi Federatsii, Moscow). 
on which I have read conference papers. ${ }^{3}$ The rest of the paper will deal with my experience of working in three Moscow archives, i.e. with what I found and what is still missing. Throughout the paper, published sources will be mentioned where appropriate, along with key questions that remain to be answered.

It is, of course, true that for a long time before 1992 much of the documentary evidence indicated that Stalin's goal was a communist, Soviet-dominated Poland. ${ }^{4}$ It was not only the largest and most populous country in Eastern Europe, but also the natural land bridge for Soviet access to Germany. Indeed, in 1920 Lenin had seen it as a Soviet bridgehead to give support to expected revolutions in Germany and Italy, and he envisaged it as a Soviet republic. It is most likely that Stalin shared these views. However, the Polish army led by Jolef Pi \sudski, defeated the Red Army at the gates of Warsaw and the Treaty of Riga of March 1921 established the Polish-Soviet frontier which left western Belorussia and western Ukraine in Poland. ${ }^{5}$ (N.B. East Galicia, i.e. western Ukraine, had never belonged to the Russian Empire. The Ukrainians and Belorussians of eastern Poland outnumbered the Poles, but the latter made up about $33 \%$ of the whole population estimated at $14,420,000$ in 1939). It also seems that Stalin, who was Political Commissar in Semen A. Budennyi's Cavalry Army in East Galicia, nursed vengeful memories of the Soviet defeat. Whatever the case may be, a question put by the Narodnyi Komitet Vnutrennikh Del (NKVD, National Committee of Internal Affairs) to all Polish officers taken prisoner in the Soviet invasion of eastern Poland in the fall of 1939 was whether they had fought in the Polish-Soviet War of 1919-1920.

3. See: Anna M. Cienciala, "Stalin and the Polish communists in World War II: A reassessment," paper read at the national convention of the American Association for the Advancement of Slavic Studies (AAASS), Philadelphia, November 19, 1994, and revised version of same: "Stalin's changing plans for Poland, 1940-1941," paper read at a joint meeting of The Kennan Institute for Advanced Russian Studies and the Woodrow Wilson Center for East European Studies, Washington, DC, March 23, 1995.

4. For documentary collections published before 1992, see: Stanislaw Biegafski et al, eds, Documents on Polish-Soviet relations 1939-1945, 2 vols (London, 1961, 1967) (based on Polish government archives in the Polish Institute and Sikorski Museum, London); Euzebiusz Basifski et al, eds, Dokumenty i materia Пy do historii stosunko@ Polsko-Radzieckich, VIVIII (Warsaw, 1973, 1974) (based on published and archival sources; Russian documents are in Russian. There is a parallel Russian edition); Antony Polonsky, ed., The Great Powers and the Polish question 1941-1945. A documentary study in Cold War origins (London, 1976) (based

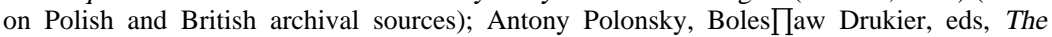
beginnings of communist rule in Poland. December 1943-June 1945 (London, 1980) (based on Polish Central Committee documents which Drukier, a former member of that body and then rektor of the party school, Warsaw, smuggled out of Poland).

5. Lenin gave the following reasons for the Bolshevik rejection of the Curzon Line proposal in July 1920: the Entente was already beaten so the Bolshevik leadership decided to go over to the offensive; it expected revolutions in Germany and Italy; the destruction of Poland would mean the destruction of the "Versailles system;" they wanted to "feel out with bayonets" whether Poland would go Soviet. For Lenin's speech at a closed session of the IX Party Congress, September 22, 1920, see: Istoricheskii arkhiv, 1 (1992): 14-29, partly quoted in Richard Pipes, Russia under the Bolshevik regime (New York, 1993): 177-183. On the military history of the war, see: Norman Davies, White eagle, red star. The Polish-Soviet war, 1919-1920 (London, 1972 and reprints); on diplomatic history, see: Piotr W. Wandycz, Soviet-Polish relations, 1917-1921 (Cambridge, MA, 1969); on Pi \sudski's federal plans, see: Marian K. Dziewanowski, Joseph Pilsudski: A European federalist, 1918-1922 (Stanford, CA, 1969). 
The Red Army entered eastern Poland on September 17, 1939, pursuant to the secret protocol in the Nazi-Soviet Nonaggression Pact of August 23, 1939. It is known that Stalin opposed the idea of a rump Polish state, and the region was annexed to the USSR. This annexation was "legalized" by rigged elections to west Belorussian and west Ukrainian Soviets in October 1939, after which these Soviets succesfully petitioned the Supreme Soviet of the USSR for union with the Soviet Belorussian and Ukrainian republics. At the same time, there were mass arrests and killings of former Polish officials and many educated Poles. Later, in 1940-1941, about $1,080,000$ or $8 \%$ of the entire population, were forcibly deported to the USSR. Just over half of this number were ethnic Poles — followed by Ukrainians, Jews, and Belorussians. An estimated 150,000 Poles survived. ${ }^{6}$ After a brief interlude of relatively friendly Polish-Soviet relations which began with the Sikorski-Maiskii Pact in late July 1941, Stalin broke off relations in late April 1943. The pretext for this step was the Polish government's request for an International Red Cross investigation of the Katyn massacre of Polish officers, discovered and publicized by the Germans on April 13 that year. (Those buried at Katyn made up about one third of the total officers reported by the Polish government as missing). In 1944-1945, as Soviet troops advanced through Poland, Stalin destroyed the Polish underground movement, which recognized the Polish government in London, and replaced its leaders with his own communist Poles. Alongside them, Stalin allowed a few symbolic democrats headed by the former premier of the government-in-exile, also

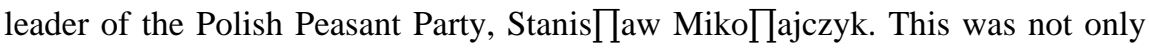
Stalin's concession to his western allies, but also a bid for the support of the largest Polish political party, much needed by the Polish communists for the time being.

Several collections of Russian documents regarding Poland were published in and after 1992, most of which appeared by summer 1994. Here it should be noted that the Soviet "cover-up" of the 1940 massacres of Polish officers in the USSR lasted until April 13, 1990, when Soviet President Mikhail S. Gorbachev handed to then Polish President Wojciech Jaruzelski a list of the names of Polish military, police, and others murdered by the NKVD in spring 1940. In October 1992, Russian President Boris N. El'tsin ordered that copies of key documents be given to Polish President Lech Wa \'sa. This led to publications in Poland, of which the most important were several small bilingual Russian-Polish volumes dealing with the Katyn massacre of Polish officers, and various aspects of Polish-Soviet relations. ${ }^{7}$ It is no exaggeration to say

6. See estimates by Dr. Marek Tuszy $f$ ski, "Soviet war crimes against Poland during the Second World War," Polish Review, 44, 2 (1999): 183-216.

7. See: Wojciech Materski, ed., Katyf. Dokumenty ludobojstwa. Dokumenty i materia Пy archiwalne przekazane Polsce 14 paêdziernika 1992 r. (Warsaw: Instytut Studio Politycznych Polskiej Akademii Nauk [ISPPAN], 1992); English translation with preface by Janusz K. Zawodny: Katyn. Documents of genocide (Warsaw, 1993). (N.B. Zawodny authored the best documented English language study of Katyn before Russian documents were accessible: Death in the forest (Notre Dame, IN, 1962 and reprints). See also the five small volumes in the series: Z archiwo sowieckich, edited by W. Materski, dealing with: Polish prisoners of war in the USSR, 1939-1941; the Polish army in the USSR, 1941-1942; Polish-Soviet conflicts 19411944; Stalin and the Warsaw rising, 1944; and the return of Home Army 
that, together with a volume of documents on NKVD action against the wartime Polish underground in 1944-1945, another with NKVD documents on the arrest and rigged trial of Polish underground leaders in Moscow in June 1944, and a volume of documents on Polish-Soviet relations in the years $1944-1949,{ }^{8}$ these publications constituted important evidence on Soviet policy towards Poland during World War II, that is, on this policy as expressed in action. There are also relevant documents in a documentary collection on Soviet security organizations' activity in World War II, and in a volume of documents on the history of the Polish-Soviet military alliance, 1941-1945. ${ }^{9}$ Furthermore, pursuant to an agreement concluded in April 1992, the directors of the Russian and Polish State Archives signed a protocol in February 1993 to publish parallel volumes of documents on the imprisonment and massacre of Polish officers in the USSR, also on the Soviet cover-up. In the meanwhile, Polish and Russian historians discovered many more relevant documents in Russian archives. As a result of all this work, the first Polish volume was published in 1995, the second in June 1998, and one Russian volume appeared in Moscow in spring 1997. ${ }^{10}$ Finally, Yale University Press appointed the author of this paper as the American editor of a volume on the Katyn and other massacres of Polish officers, also on the cover-up, in its series The annals of communism. Nataliia S. Lebedeva, the preeminent Russian authority on the Katyn massacre is the Russian co-editor, ${ }^{11}$ and

soldiers from the USSR. All these documents, received from the Russian government, were published with parallel Russian and Polish texts by ISPPAN (Warsaw, 1992-1995).

8. Albin F. Noskova et al., eds, NKVD i pol'skoe podpol'e 1944-1945 gg. (po “osobym papkam" I. V. Stalina) (Moscow: Institut slavianovedeniia i balkanistiki RAN, 1994). Andrzej Chmielarz, Andrzej Krzysztof Kunert, eds, Proces szesnastu. Dokumenty NKWD (Warsaw, 1995) (Polish translations of materials supplied by the Russian Military Prosecutor General's office). See also: Gennadij A. Bordiugiew, Aleksander Kochafski, Adam Koseski, Gennadij F. Matwiejew, Andrzej Paczkowski, eds, (Polish transliteration of Russian names), Polska-ZSRR. Struktury podleglosci. Dokumenty KC WKP(b) 1944-1949 (Warsaw, 1995); Russian edition with same editors: SSSR-Pol'sha: mekhanizmy podchineniia 1944-1949 gg. Sbornik dokumentov (Moscow: AIRO-XX, 1995).

9. Organy gosudarstvennoi bezopasnosti SSSR v Velikoi Otechestvennoi voine. Sbornik dokumentov, vol. 1 (Moscow: Kniga i Biznes, 1995). See also: Andrzej Chmielarz, Wojciech Materski, Andrzej Paczkowski, eds, NKWD o Polsce i Polakach. Rekonesans archiwalny (Warsaw: ISPPAN, 1996) and. V.A. Zolotorev et al., eds, SSSR i Pol'sha. 1941-1945. K istorii voennogo soiuza. Dokumenty i materialy, vol. 14. 3 (1) in the series Russkii arkhiv. Velikaia Otechestvennaia (Moscow: Terra, 1994). The editors state erroneously that general W. Anders served in the German army in 1918, and that he was a "descendant of Baltic barons," (p. 13, note 3 ). The volume lacks documents on the raising of the second Polish army in the USSR under general Zygmunt Berling in 1943-1944.

10. Katyf. Dokumenty zbrodni. Tom 1. Jefcy niewypowiedzianej wojny: sierpief 1939-marzec

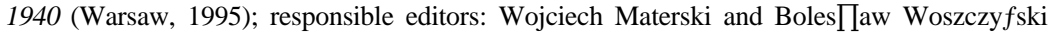
assisted by historian Ewa Rossowska, with Prof. Nataliia Lebedeva and archivist Nelli A. Petrosova as the responsible Russian editors. The first Russian volume appeared in spring 1997 titled: Katyn'. Plenniki neob"iavlennoi voiny (Moscow: "Demokratiia," 1997), with N. Lebedeva listed as the responsible Russian editor; W. Materski was the responsible Polish editor though not designated as such. This work was published in the series: "Rossiia. XX Vek" with a preface by Aleksandr Iakovlev, head of the Democracy Fund which provided a subsidy for its publication.

11. See Nataliia S. Lebedeva, Katyn'. Prestuplenie protiv chelovechestva (Moscow, 1994), Id., "Chetvertyi razdel Pol'shi i katynskaia tragediia," in: Iu. N. Afanas'ev, ed., Drugaia voina: 1939-1945 (Moscow, 1995). 
Professor Wojciech Materski - who edited previous collections of Russian documents - is the Polish co-editor. The volume is due to appear in 2000.

Given this historical background and the published documents, my research goal in Moscow was to find Russian documents illustrating Stalin's concepts of postwar Poland at different periods of the war. Regarding the immediate prewar and early-war period, studies published a long time before 1992 indicated that Stalin considered organizing a new Polish communist party in 1939 to replace the one he had dissolved in 1938, whose leaders he killed in the purges of the years 1936-1938. Thus, a group of hand-picked, Polish communists called the "Paris initiative group" was organized in Paris in January 1939. They published three issues of a periodical titled Information Bulletin, which was smuggled into Poland. The first issue called for a "united front" of all Polish parties to create a government of national unity. However, the third and last issue, published in April - i.e. just after the announcement of the British Guarantee of Polish independence of March 31 - called for the overthrow of the existing Polish government. Here, two questions arise: What did Stalin have in mind when he allowed the Paris group to come into being and publish its Bulletin? Did the writers of the Bulletin go beyond a brief sanctioned by Moscow, or did Stalin end the short-lived publication because he no longer needed it? Whatever the case may be, he shelved these Polish communists sometime in the spring of 1939, and this might have been connected with the revival of Soviet-German talks on an economic agreement. (The group remained in Paris until the fall of France in mid-June 1940, after which they travelled to the USSR). Despite the Bulletin's demise, the Ispolnitel'nyi Komitet Kommunisticheskogo Internatsionala (IKKI, Executive Committee of the Comintern) resolved on May 16, 1939 to reactivate the Polish Communist Party. Ten days later, IKKI established a new "initiative group" on Polish affairs attached to the Comintern. It was to be led by three Polish communists then in the Paris initiative group, headed by one of the heroes of the Spanish Civil War, BolesПaw MoПojec. ${ }^{12}$ However, no steps were taken to reactivate a Polish Communist Party until April 1941. The question is: Why was this matter allowed to lapse for so long? Perhaps this was so because Stalin decided to pursue not just an economic but also a political agreement with Hitler, and having achieved it, did not see any need to create a new Polish communist party?

As regards Soviet policy towards Poland between 1939 and 1941, Russian documents handed over to the Polish government in October 1992, as well as others published later, confirm what many Poles had believed for decades. They show that Stalin intended to destroy the leading civilian and military cadres of the Polish state - which was also the policy of Nazi Germany. On September 19, 1939,

12. See notes by Jakub Berman, cit. in Marian Malinowski, Geneza PPR, 2d rev. ed. (Warsaw, 1975): 41-43; see also: N. S. Lebedeva, "The Comintern and Poland in 1939-1943," International Affairs, 8 (Moscow, 1993). For an English language history of the Polish communists, see: B. de Weydenthal, The communists of Poland. An historical outline, 2 rev. ed. (Stanford, CA, 1986). Berman, a prewar communist, was an instructor at the Comintern party school, also a member of the Polish communist leadership in the USSR and later in postwar Poland until October 1956. 
pursuant to a decision of the Politbiuro, the Commissar of National Defense, marshal Kliment E.Voroshilov, issued a directive that the Red Army hand over Polish officers taken prisoner in the previous month to the NKVD. Soon thereafter, these officers were relocated to three camps: Starobelsk, in Ukraine, also Kozelsk and Ostashkov in western Russia. (The last camp held police, border guards, and various civilians). In late 1939, NKVD officers started interrogating the prisoners. (As mentioned earlier, one of the questions asked of each prisoner was whether he had fought in the Polish-Soviet War of 1919-1920). Finally, on March 5, 1940, the Politbiuro approved a resolution proposed by Lavrentii P. Beriia, Commissar of the NKVD stating that the 14,700 officers and other prisoners in the three camps, as well as the 11,000 held in NKVD prisons in western Belorussia and western Ukraine, were unregenerate enemies of the Soviet Union and should be executed without trial. ${ }^{13}$ The vast majority were executed, but 432 were spared from the camps, to be joined in summer 1940 by officers who had been interned in Lithuania.

It should be noted that apart from its administrative control over these prisoners, the NKVD was also involved in hunting down specific categories of Poles. In accordance with Beriia's directive issued on September 15, 1939 - two days before the Soviet entry into eastern Poland - the NKVD arrested members of Polish military intelligence, police, administration, and political leaders. Furthermore, as noted earlier, in 1940-1941, about $1,080,000$, or $8 \%$ of the population, qualified as "undesirable," were deported into the Soviet interior, mostly to labor camps. It is also known that a large number of former Polish communists, who had sought refuge from the Germans under Soviet rule, were arrested and shot. Many others were deported, while most of those who stayed were left without work and ration cards, i.e. without the means of survival. Appeals for help on their behalf fell on deaf ears and it was only in July 1940 that the head of the Comintern, Georgii M. Dimitrov, wrote Georgii M. Malenkov, head of the Central Committee's cadre administration, asking that these people be helped and accepted into the Belorussian and Ukrainian parties. ${ }^{14}$ This was done, but those who had

13. For the Politbiuro's decision on the prisoners, Voroshilov's order of September 1939, and the Beriia resolution and Politbiuro approval of March 5, 1940, see: Katyf. Dokumenty zbrodni, op. cit.: doc. nos. 9, 10, 217; Katyn. Plenniki..., op. cit.: same doc. nos. For lists of names of executed prisoners from the three camps and names of prisoners who were spared, see: J'drzej Tucholski, Mord w Katyniu (Warsaw, 1991). The volume includes some NKVD documents (in Russian) published later in the Polish and Russian Katyn volumes. Polish scholars cite the total number of Polish prisoners executed by the NKVD in spring 1940, counting both those from the three camps and those in west Belorussian and west Ukrainian prisons, as 21,857; these included military officers as well as civilians, mostly civil service officials.

14. For Beriia's directive of September 15, 1939, see: Organy gosudarstvennoi bezopasnosti SSSR..., op. cit., vol. I., doc. no. 33. For studies on the Soviet regime in eastern Poland, 19391941 and deportations, based on Polish documentation, see: Norman Davies, Antony Polonsky, eds, Jews in eastern Poland and the USSR, 1939-1946 (New York, 1991); Jan T. Gross, Revolution from abroad. The Soviet conquest of Poland's western Ukraine and western Belorussia (Princeton, NJ, 1988); Keith Sword, ed., The Soviet takeover of the Polish eastern provinces, 1939-1941 (New York, 1991); Id., Deportation and exile. Poles in the Soviet Union, 
been deported elsewhere still lacked work and ration cards, so that many died before help was finally authorized for them.

The Soviet measures cited above indicate that Stalin's goal was to liquidate Polish "bourgeois" cadres as well as many former Polish communists. Most of the latter were suspect simply because of their membership in the condemned Polish Communist Party. These measures did not, however, mean that Stalin had no interest in any kind of future Poland. Indeed, while the above-mentioned Poles were being arrested or liquidated, some Polish left-wing intellectuals and selected communists were active under the leadership of the writer Wanda Wasilewska in Lvov (Ukrainian: L'viv, Polish: Lwo@, Russian: L'vov), west Ukraine, from the autumn of 1939 to June 22, 1941. They published newspapers and worked on Polish language textbooks for schools. In October 1940, a Soviet policy of emphasizing Polish history and culture was noted by the Poles. It was accompanied by decreasing pressure to ukrainize the city, also by rumors on the raising of a "Polish Legion." In November 1940, the left-wing group organized a much touted celebration of the Polish national poet, Adam Mickiewicz (1798-1855), on the occasion of the 85th anniversary of his death. He was presented as a poet of the people. (Some Polish intellectuals remarked snidely that Mickiewicz was being made over into a Bolshevik). All this indicates Stalin's interest in nurturing this particular group of Poles for future use. ${ }^{15}$

The rumors about a "Polish Legion" might have been spread by the Wasilewska group and/or by Soviet authorities to encourage Polish officers to come out of hiding — perhaps to fill a need. Indeed, Russian documents show that in October

1939-1948 (London, 1994) (cites a few Russian documents). For studies on deportations based on Russian documents, see: V.S. Parsadanova, "Deportatsiia naseleniia iz zapadnoi Ukrainy i

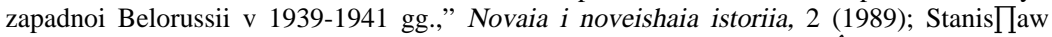
Ciesielski et al., eds, Masowe deportacje radzieckie $w$ okresie II wojny $\hat{E}$ wiatowej, 2nd ed. (Wroclaw, 1994). On Polish communists in western Belorussia and western Ukraine, see N. S. Lebedeva, "The Comintern and Poland...," art. cit., and for Dimitrov's letter to Malenkov of July 30, 1940, see Nataliia S. Lebedeva, Mikhail M. Narinskii, eds, Komintern i vtoraia mirovaia voina. Chast' I. do 22 iuniia 1941 (Moscow, 1994) doc. no. 112: 399-400, 400-401 (note). In October 1939, Dimitrov himself had sent the NKVD two letters with lists of 500 persons suspected of "provocatory" actions in connection with the activity of the Ukrainian and Belorussian communist parties, see ibid.: 137, note 1.

15. See Bogdan Czaykowski, "Soviet policies in the literary sphere: Their effects and implications," and Mieczys \aw Inglot, "The socio-political role of the Polish literary tradition in the cultural life of Lvov: The example of Adam Mickiewicz's work," in Keith Sword, ed., The Soviet takeover ..., op. cit.: 102-148. For the sudden emphasis on Polish history and culture in October 1940, accompanied by rumors of a "Polish Legion," as well as snide remarks on Mickiewicz being made over into a Bolshevik, see: Tadeusz Tomaszewski, Lwo@. Pejsa§ psychologiczny (Warsaw, 1996): 27, 44. These are diary notes by a young Polish psychologist, covering the period 1940-1945. Earlier rumors about the raising of "Red Polish Legions" in former eastern Poland were reported by the British representative in Kaunas, Lithuania, in June 1940, and in July by Kazimierz Papée, Polish ambassador to the Vatican. They may have been connected with a Soviet-inspired proposal made in London in late June to the head of the Polish

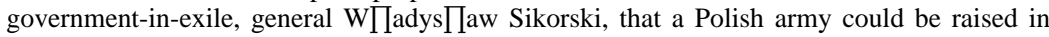
former eastern Poland in return for Polish recognition of the Soviet western frontier as established in late September 1939, see: Henryk Batowski, Polska dyplomacja na obczyênie, 1939-1941, 2nd rev. ed. (Krako@, 1991): 301-302, also A. M. Cienciala, "The question of the Polish-Soviet frontier...," art. cit. 
1940 high NKVD officials interviewed Polish officers held in the Lubianka prison, Moscow, with a view to forming a Polish unit in the Red Army. Ultimately, they chose colonel Zygmunt Berling and a few others who had declared readiness to serve. They were ordered to draw up plans for a Polish division in the Red Army. Several months later, on June 4, 1941, the Politbiuro ratified a decision by the National Commissariat of Defense, that this division be established by July 1, 1941. ${ }^{16}$ Several questions come to mind here: Why and when did Stalin order the NKVD to select certain Polish officers to be spared for eventual future use? What were the criteria in making such selections? When did Stalin give orders for interviews to begin? What was to be the political significance of this Polish division? Whatever the answers - and they may be connected with increasingly tense German-Soviet relations - these documents indicate that Stalin was thinking of a Polish unit in the Red Army, perhaps as military cadres for a future communist Poland. Indeed, on June 22, 1941, the day on which Nazi Germany attacked the USSR, a declaration by Berling and his companions - which Berling claimed was dictated to them by the NKVD - spoke of a future, reborn Poland as part of the USSR. However, a declaration made at the same time by a group of Polish communists spoke of fighting against the Germans for "a free and independent Poland." 17 Whatever this meant, it seems that they and their IKKI mentors were better attuned to Polish sensibilities than Berling and the NKVD.

The plan to create a Polish division was shelved with the signing of the SikorskiMaiskii Pact in London on July 30, 1941. It should be noted that original Soviet proposals for this agreement included a future "ethnic" Poland (i.e. minus former eastern Poland) and the immediate establishment of a "Polish National Committee" in the USSR which would raise a Polish armed force there. However, the Polish government's opposition and the need for British military help led Stalin to give up these proposals, at least for the time being, while the Poles gave up their demand for official Soviet recognition of the prewar (Riga) Polish-Soviet frontier. (This issue was left in suspense, though each side proclaimed its version of what the agreement signified on frontiers). The Sikorski-Maiskii Pact restored Polish-Soviet relations and the two sides declared they would support each other in the war against Germany. Furthermore, Polish prisoners were to be "amnestied" (a face saver for the Soviet government) and a Polish army was to be raised in the USSR. ${ }^{18}$ The questions that come to mind here are the following: What were Stalin's thoughts during these negotiations? What were his directives to the Soviet ambassador in London, Ivan Maiskii? What kind of agreement did Stalin hope to reach with the

16. For Beriia's note to Stalin of November 2, 1940 with information on groups of selected Polish officers, see: W. Materski, ed., $Z$ archiwo@ sowieckich. T. 1: Polscy jefcy wojenni $w$ ZSSR, 1939-1941 (Warsaw: ISPPAN, 1992): doc. 7. (p. 2 is missing because it was missing in the Russian xerox copies handed to the Polish government in October 1992. The full text is available in the Archives of the President of the Russian Federation, Moscow).

17. For these declarations, made on June 22, 1941, see: Dokumenty i materia Пy do historii stosunko@ polsko-radzieckich (Warsaw, 1973) VII: docs 126, 132.

18. See A. M. Cienciala, "General Sikorski...”, art. cit. 
premier of the Polish government-in-exile and commander-in-chief of Polish

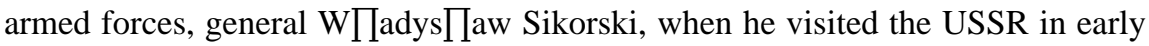
December 1941 to discuss with Stalin problems relevant to the Polish army and visit the troops? Did Sikorski's disinclination to discuss changes in the PolishSoviet frontier have any impact on Stalin's decision to send the first leading cadre of the Polish Workers' Party (PPR) to Poland at the end of December 1941? (These matters will be discussed at more length later in this paper).

As mentioned earlier, Stalin severed relations with the Polish government in London in late April 1943. The pretext was that government's request for an inquiry by the International Red Cross into the massacre of Polish officers whose graves were found by the Germans at Katyn, near Smolensk. It has been known for some time, however, that this was no sudden decision for Stalin for he had told Wanda Wasilewska at the end of January 1943 that he expected a break in relations with the London Poles. Therefore, he told her, a new Polish organization was to be established in the USSR, which he named the "Union of Polish Patriots." He also decided that the first issue of its newspaper, which he named Free Poland, was to appear on March $1 .{ }^{19}$ At roughly the same time, in February, talks took place in German-occupied Warsaw between the Polish underground leadership and the PPR leadership, but no agreement was reached. The PPR wanted to discuss the establishment of a postwar Polish government, which might include Sikorski; it also demanded a seat in the High Command of the Home Army, the underground's military organization. The Home Army command rejected these demands. ${ }^{20}$ I found no documents on the Stalin-Wasilewska and PPR-Home Army conversations in the Russian archives. On the second matter, the following questions arise: Was this a PPR initiative sanctioned by Moscow, or was it undertaken independently from Moscow? Either way, what was Stalin's thinking on these talks?

As mentioned earlier, I had hoped to find documents which would help answer all these questions. I was particularly interested in documenting Stalin's changing conceptions of postwar Poland, a topic I had studied previously through published documents on the Polish Workers' Party (PPR). ${ }^{21}$ In summer 1994, I spent eight weeks in Moscow reading documents relevant to Soviet policy on Poland in World

19. On the Wasilewska-Stalin talks at the end of January 1943, see her memoirs, "Wspomnienia Wandy Wasilewskiej (1939-1944)," Archiwum Ruchu Robotniczego, (Warsaw, 1982) VII: 382. On the Union of Polish Patriots in the USSR, their ideology and programs, see: Zbigniew KumoÊ, Zwiàzk Patrioto@ Polskich. Za loßenia programowo-

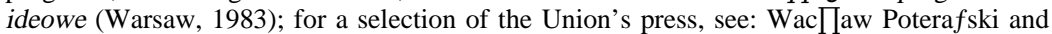
Maria Wilusz, eds, Publicystyka Zwiàzku Patrioto@ Polskich, 1943-1944. Wyboe(Warsaw, 1967). For a study of Wanda Wasilewska's wartime activity, see: Eleonora Syzdek, Dzia \alnoÊç Wandy Wasilewskiej w latach drugiej wojny $\hat{E}$ wiatowej (Warsaw, 1981).

20. On the PPR-Underground Army Command talks in German-occupied Poland in early 1943, see: A. M. Cienciala, "The activities of Polish communists as a source for Stalin's policy towards Poland in the Second World War," The International History Review, VII, 1 (1985): 129-145. (N.B. p. 133, note 14, erroneously cites Wasilewska's reminiscences published in Archiwum Ruchu Robotniczego as vol. III; it should be VII).

21. See note 19 above. 
War II in three archives: (1) Rossiiskii Tsentr Khraneniia i Izucheniia Dokumentov Noveishei Istorii (RTsKhIDNI, The Russian Center for Preservation and Study of Documents of Contemporary History, formerly the Tsentral'nyi Partiinyi Arkhiv, TsPA, Central Party Archives); (2) Arkhiv Vneshnei Politiki Rossiiskoi Federatsii (AVP, The Foreign Policy Archives of the Russian Federation); and (3) The Tsentr Khraneniia Sovremennoi Dokumentatsii, (TsKhSD, The Center for Preservation of Contemporary Documentation) which includes documents released from the Archives of the President of the Russian Federation. Here I would like to note that in applying for an IREX grant in October 1992 and writing for permission to work in the first two archives listed above (I applied to the third when I was already in Moscow), I lacked two important items of information: (1) that key documents dealing with foreign policy and defense were located in Stalin's "special files," which were then in the inaccessible Presidential Archive, Kremlin, though some had been released on various occasions to other archives; (2) that the declassification schedule for the AVP, indicating when some of its documents were to be accessible, had a gap for the years 1927-1945. I had not seen any mention of the first, and did not know about the second because, not being a student of the "Cold War," I did not receive the relevant bulletin before I left for Moscow.22 I did, however, know that the RTsKhIDNI lacked certain materials of the former Central Party Archives, e.g. materials from the Central Committee's General Department, as well as documents on CC plenums and Politbiuro protocols after 1940, while those Politbiuro protocols for 1919-1940, that were accessible, had considerable gaps, including foreign policy materials. ${ }^{23}$ Finally, I had heard that commission reports and other materials on which Politbiuro decisions were based, were still inaccessible. ${ }^{24}$ (I will discuss lacunae in the other two archives as I come to them). Despite this depressing information, I hoped that at least some of these materials might be declassified and available by the time I arrived in Moscow. Furthermore, my letters to the archive directors specified my interest in Soviet wartime policy on Poland, and in granting me permission to do research on this topic, they did not indicate that most of the relevant documents were still inaccessible.

In the three archives listed above, I did not, of course, find the type of documents located in British, American, and Polish government archives, i.e. Cabinet papers;

22. On Stalin's special files, see Raymond L. Garthoff, "Some observations on using the Soviet archives," Diplomatic History , 2 (1997): 245. For a catalog of these special files for the years 1944-1953, see: V. A. Kozlov, S.V. Mironenko, eds, Arkhiv noveishei istorii Rossii. T. I: “Osobaia papka” I. V. Stalina. Iz materialov Sekretariata NKVD-MVD SSSR 1944-1953 gg. Katalog dokumentov (Moscow, 1994). According to the established declassification schedule for the AVP, documents for 1917-1922 were to be declassified by 1993, and those for 19221927 and 1945-1953 by September 1994, but the dates 1928-1945 were omitted, see: Vladimir V. Sokolov, Sven S. Holtsmark, "Notes on the Foreign Policy Archive of the Russian Federation," Bulletin. Cold War International History Project. Woodrow Wilson International Center for Scholars (Washington, DC), 3 (Fall 1993): 26.

23. See: J. Arch Getty, V. P. Kozlov, eds, Kratkii putevoditel'. Fondy v kollektsii, sobrannye Tsentral'nym Partiinym Arkhivom (Moscow, 1993): XII. This is now the RTsKhIDNI.

24. See: Michael David Fox, David Hoffmann, “The Politburo protocols, 1919-1940," The Russian Review (January 1996): 99-103. 
Prime Minister papers; instructions to ambassadors and their reports; written opinions of high government officials and their discussions, either in letters or marginal comments. (The latter are especially useful in British Foreign Office documents). Nor did I find reminiscences and notes by key Soviet personalities, such as those available on the Polish side from Wanda Wasilewska and Jakub Berman. ${ }^{25}$ However, I did find much interesting and valuable material which cast an indirect light on Stalin's thinking and thus his policies regarding Poland.

In the RTsKhIDNI, I concentrated on reading papers relevant to Poland in the Comintern Archives, i.e. in the Georgii M. Dimitrov and the Dimitrii Z. Manuil'skii Secretariats. (G. M. Dimitrov was Secretary General of the Comintern from 1935 to 1943 , while D. Z. Manuil'skii seems to have been Stalin's official spokesman there). In reading these files, I found Nataliia S. Lebedeva's article "The Comintern and Poland" very helpful. The volume of documents she edited with M. M. Narinskii on the Comintern and World War II appeared after I left Moscow, but this excellent collection contains only one document dealing directly with Polish communists in the USSR. ${ }^{26}$ It is known that after the "dissolution" of the Comintern in May 1943,27 Dimitrov and Manuil'skii continued their work with Polish communists, but did so in the "International Information Department" of the Central Committee, subsequently renamed the "Foreign Policy Department." I read some of the files belonging to these two departments, which hold documents mainly for 1944. ${ }^{28}$ The Comintern's "Department of Special Communications," which handled couriers and radio stations was renamed the "Scientific Research Institute no. 100." The latter was closed to researchers, at least when I was there. The justification was that it contained cypher communications which were still classified. I was surprized to hear this, since at least some of them had been published in Poland and the USSR many years ago, while a large collection of cyphers is accessible in the AAN, Warsaw. ${ }^{29}$

In fond 495, opisi 74 (Dimitrov) and 10a (Manuil'skii), I found much interesting material on Polish communists in 1939, 1940-1941 (to June 22, 1941), and then in 1944, but very little on the following: the Polish communists in the USSR in 1942-

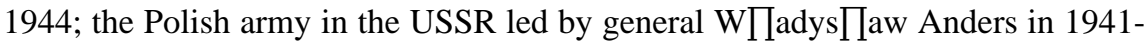
1942 (there are some spy reports); and the Polish army in the USSR in 1943-1944, led by general Zygmunt Berling. (He was promoted to general in spring 1943).

25. For Wasilewska's memoirs, see note 18 above; for J. Berman's papers, see: AAN, Warsaw, Archiwum KC PZPR, "SpuÊcizna Jakuba Bermana."

26. See Dimitrov's letter to Malenkov of July 30, 1940 in N. S. Lebedeva, M. M. Narinskii, eds, Komintern $i$ vtoraia mirovaia voina..., op. cit.

27. See N. Lebedeva, M. Narinsky, "Dissolution of the Comintern in 1943," International Affairs, 8 (1994): 89-99.

28. Many of these documents were published in 1995, see SSSR-Pol'sha..., op. cit.

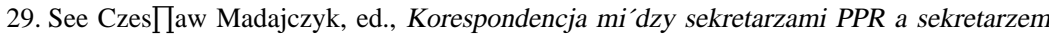
generalnym Mi'dzynarodo@ki Komunistycznej (Warsaw, 1967). (The 37 radio telegrams in this collection cover the period June 11, 1942-May 11, 1943). See also AAN, Warsaw: “Archiwum lewicy polskiej," collection: KC PZPR, A.190/ 1-13; A.248/12. 
Some Russian documents on the Anders army were published in Poland, and more documents on the two Polish armies may well be located in the NKVD/GRU (Glavnoe Razvedyvatel'noe Upravlenie - Central Intelligence Admisnistration) archives because copies of selected documents on the Polish army in 1941-1942 from the Presidential archive in the Kremlin — given to the Polish government in October 1992 and published in Poland later that year - are NKVD documents. ${ }^{30}$ Furthermore, the Soviet liaison officer with both Polish army leaders was the NKVD major, later general, Georgii S. Zhukov (not to be confused with marshal Georgii K. Zhukov). This officer is frequently and favorably mentioned by Berling in his memoirs. ${ }^{31}$ Nor did I find any material on the left-wing Polish group in L'viv, 1939-1941, even though Sofiia Dzerzhinskaia is known to have supervised their activities and their newspaper, Nowe Widnokr'gi. Sofiia Dzerzhinskaia was the widow of Polish communist leader Feliks Dzerzhinskii - F. Dzier§y $f$ ski - the first head of the Cheka. Moreover, it is known that Wanda Wasilewska, who became a member of the Ukrainian Communist Party and a deputy to the Supreme Soviet from L'viv, saw Stalin at least twice during this period of time, but I found no Russian records of these conversations.

The bulk of the material in the opisi I studied in fond 495 for 1940-1941 dealt with individual Polish communists in the USSR. I did, however, find a most interesting document which may cast some light on Stalin's thinking about Poland in spring 1941. This is a letter to G.M. Dimitrov of April 30, 1941, written by Sofiia Dzerzhinskaia. Sofiia was a member of IKKI and as "political referent" for Poland she reported to Dimitrov and Manuil'skii. In her letter, she reported on a meeting and conversation which took place on April 15 between her, and her son Jan "senior referent" for Poland, and NKVD officer — on the one side, and some

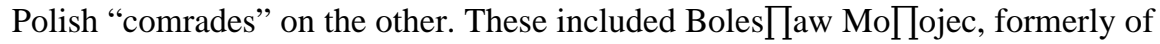
the "Paris initiative group," and Marceli Nowotko, a second string activist who, like many minor Polish communists, had survived Stalin's purges because he was imprisoned in Poland. ${ }^{32}$ The conversation concerned the establishment of a new Polish communist party. In her letter, Sofiia was very critical of MoПojec, whom she accused of having a swelled head from his exploits in the Spanish Civil War, as well as for his work on the Information Bulletin in 1939, which she condemned for

30. See: W. Materski, ed., Z archiwo sowieckich. Tom II: Armia polska w ZSSR 1941-1942 (Warsaw, 1992). As in all volumes of this series, the original Russian documents are printed in

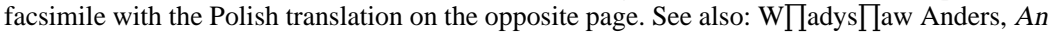
army in exile; the story of the Polish Second Corps (London, 1949); reprint : Knoxville, TN, 1981 and K. Sword, ed., Deportation and exile, op. cit.

31. See: Zygmunt Berling, Wspomnienia. T. I: Z Magro@ do Andersa (Warsaw, 1990). These interesting memoirs contain many innaccuracies, so they must be checked against the excellent

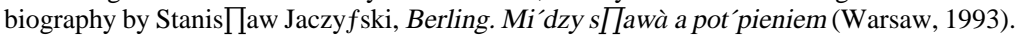

32. Marceli Nowotko became the first head of the new party in late 1941, but was assassinated

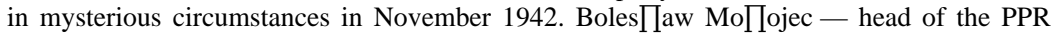
military arm - and his brother Zygmunt, who allegedly carried out the assassination at his brother's bidding, were executed on party orders. It is still not clear whether B. MoПојеc actually ordered his brother to kill Nowotko, and if he did, whether he acted on his own initiative, see K. Kersten, op. cit.: 11-12. 
spreading the "wrong ideas." She also criticized him for seeing himself as the leader of the future Polish communist party. She noted that MoПojec rejected the charge used by the Comintern to justify the dissolution of the Polish party in 1938, i.e. that it had been infiltrated by the Polish police. He should, she wrote, carry out "self-criticism" for his errors in the Information Bulletin (errors that she did not spell out), also for the "unacceptable tone" of his letter to Dimitrov of April 2. (The letter was not in the file, but it is clear that MoПojec had demanded a meeting with Dimitrov).

Despite MoПojec's attitude, and despite the fact that the "comrades" defended their participation in the defense of "bourgeois" Poland against the Germans in September 1939, Sofiia read to them the Comintern resolution of May 16, 1939 that the Polish party was to be reconstructed. This, she noted, made them very happy. (The text of the resolution is missing from the file.) She suggested to Dimitrov that these comrades needed Polish instructors in the party school they were attending. ${ }^{33}$ She added that they should study materials "unmasking" the true history of the old Polish party. Finally, she noted that they should be aided to work out a party platform "at the given time." 34

In fact, Dzerzhinskaia herself drew up a draft program for the new party, which she sent to Dimitrov in the form of a memorandum, dated April 18. This was an uninspired grab bag of communist political, economic, and social slogans. The suggested "platform" included standard socialist demands, but declared that the immediate task was "the struggle for national liberation of the Polish people from the yoke of German imperialism." The Polish Socialists (Polish acronym PPS) and Peasant Party (Polish acronym SL) - who were already resisting the Germans in occupied Poland - were labelled "agencies of Anglo-American capitalism." The new party was to lead national resistance — but also unmask "the anti-national and anti-Soviet character of the so-called Sikorski government and the so-called Polish Legion." (There was no such legion, but there were Polish armed forces in Great Britain; the Polish Highland brigade, originally in French Syria, which moved to Egypt to fight on the British side; and the underground movement in Poland, which recognized the Polish government in London - A.C.) After overthrowing imperialism, the party would establish "the worker-peasant power of the proletariat." There followed a list of the standard political, social and economic reforms to be carried out - many of which were long part of the PPS and SL programs - but the key task was the establishment of "a national liberation front"

33. Polish sources indicate that Polish communists began to attend this school in the early fall

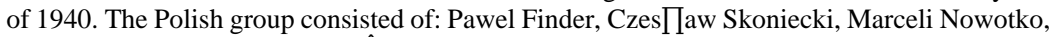
Jakub Aleksandrowicz, Roman Âliwa, Anastazy Kowalczyk, Jan Turlejski, Lucjan Partyfski,

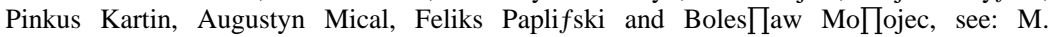
Malinowski, op. cit.: 345 . This was a one-year party school, as proposed on behalf of IKKI in Dimitrov's letter to A. A. Andreev of August 31, 1940. It was located first at Nagorno, but later moved to Pushkino. See: N. S. Lebedeva, M. N. Narinskii, eds, Komintern i vtoraia mirovaia voina..., op. cit., I, doc. no. 118: 424-425, 426 (note).

34. S. Dzerzhinskaia, letter of April 30, 1941, to G. M.Dimitrov, RTsKhIDNI, f. 495, op. 12, d. 105, 11. 16-22. 
against the Germans. Therefore, Dzerzhinskaia proposed the following: that a provisional party center be set up; that contacts be established with communists in Poland; that a party organ (newspaper) be established to explain Comintern decisions and direct the work of communists in Poland; also that [political] work be carried out among Polish emigrants in the USA, Canada, Latin America, and France. ${ }^{35}$

Polish communist sources indicate that the party "platform" (program) was discussed by the students at the party school and hammered out under Dimitrov's guidance sometime in the fall of 1941 - but there is only a faint trace of this in the files of the Dimitrov Secretariat. Furthermore, it is not clear whether this platform was finalized before the crash, at take-off in Vyazma, of the airplane carrying the first cadres to Poland in September 1941. ${ }^{36}$ It can be assumed that Dzerzhinskaia's April talk with the Polish comrades was sanctioned by Stalin. However, the "platform," as finalized in the fall of 1941, omitted attacks on the prewar Polish Communist Party, the socialist and peasant parties, and the Sikorski government. Clearly, Stalin's policy was modified to some extent by the conclusion of the Sikorski-Maiskii pact of July 30, 1941 and the Sikorski-Stalin talks in Moscow on December 3-4, 1941, but he still took care to have his Polish communists transported to Warsaw, and later to other localities in German-occupied Poland. The initial PPR cadre group, carrying a microfilm of the progam and two radio stations, was parachuted from a Soviet plane onto the outskirts of Warsaw at the end of December 1941. Their activities indicate that their goal was to attract support from the socialist and peasant parties so as to split the underground movement and then take over the leadership, but they never gained any significant support.

As I worked in the RTsKhIDNI, I also looked for documents on Stalin's Polish policies in the Foreign Policy Archives of the Russian Federation, AVP, dividing my time between the two archives. In summer 1994, the AVP had no catalog, only a list of Foreign Ministers' and Deputy Foreign Ministers' Secretariats, as well as "Referenturas" for various countries. I was particularly interested in the negotiations for the Sikorski-Maiskii pact, the Sikorski-Stalin and the Stalin-Eden talks in Moscow in December 1941. I had hoped to find Russian documents throwing light on Stalin's thinking on the latter, for which Polish and British records have been available for a long time. ${ }^{37}$ However, I did not find anything on the Sikorski-Maiskii Pact, and nothing to illustrate Stalin's thinking on Sikorski's visit to Moscow in early December. The Russian records of some Russian-Polish

35. S. Dzerzhinskaia, memorandum to Dimitrov, April 18, 1941, ibid., 11. 4-11.

36. For a summary of the drafting process, based on Jakub Berman's account, see: M. Malinowski, op. cit.: ch. 10. For a full account, see: AAN, Warsaw, Jakub Berman collection, 245/2, pp. 8 ff. For the final text as published see: Polska Partia Robotnicza. Dokumenty programowe 1942-1944 (Warsaw, 1984) doc. no. 1: 51-55 and note 1: 55.

37. For Sikorski's account of his talk with Stalin as told to the British Ambassador in the USSR, see: Sir Stafford Cripps to Anthony Eden, December 6, 1941, in: A. Polonsky, ed., The Great Powers..., op. cit., doc. 30: 95-98 (also other documents cited there). 
diplomatic conversations preceding the Sikorski-Stalin conversation of December 3, 1941, as well as a record of that particular conversation were published in Russia in 1990, then in English translation in 1991. (It is worth noting that in that conversation, which concerned the Polish army in the USSR, when Sikorski asked about the missing Polish officers, Stalin replied that all Polish prisoners of war had been released, but suggested that some of them might have left on their own for Manchuria - then under Japanese occupation! This may be an example of Stalin's "black" humor.) ${ }^{38}$ Still, I hoped to find another copy of the Russian record in case it had marginal notes or comments. Indeed, I found a listing for the Sikorski-Stalin conversation of December 3, 1941 in one of the files of the Molotov Secretariat. Alongside this listing, however, there was a note in red ink stating the record had been transferred to the archives of the Central Committee. The note is dated March 7, 1953, i.e. just after Stalin's death. ${ }^{39}$ When I asked about this document at the AVP, I was advised to inquire if it was at the RTsKhIDNI. There I was told to try the Archives of the President of the Russian Federation in the TsKhSD. On inquiring there, I was told they did not have it, so it was presumably in the Presidential Archives housed in the Kremlin — which were virtually inaccessible.

I did, however, obtain access in the AVP to Deputy Foreign Minister Andrei Ia. Vyshinskii's Secretariat, which proved to be of interest for 1941. This contains his letter to Molotov reporting on Sikorski's tour of Polish military units in December, after his visit to Moscow. At one point, both men were in a room at general Anders' headquarters, which had a large wall map of the USSR and its western borderlands. Sikorski looked at it for a while and said the two nations should be friends. He also said Stalin had told him that they would not quarrel over territory, and that Lvov (L'viv/Lwo@) was a Polish city. Stalin, continued Sikorski, thought the Poles would have problems with the Ukrainians, but promised to help. ${ }^{40}$ I ordered a xerox copy of this letter, but was told on leaving that it was not ready, so I could empower a friend to pick it up later. However, when this friend tried to do so, she was told the document belonged to a category that could not be xeroxed - so I was very glad that I had made extensive notes of my own. This Vyshinskii letter complements one of the Russian documents on the Eden-Stalin talks edited by Oleg Rzheshevskii, first published in Russia in spring 1994. One of the draft Soviet protocols to the treaty — which does not seem to have been presented to Eden — stated that Poland

38. See N. Lebedeva, ed., "Stalin, Sikorskii, Anders i drugie,” Mezhdunarodnaia zhizn', 12 (1990); the text of the Stalin-Sikorski conversation (pp.134-140) is taken from AVP, f. 048, op. 52a, p. 258, d. 2; for the same in English translation, see: "Stalin, Sikorski, Anders et al.," International Affairs, 1 (1991): 126-132.

39. See AVP, Molotov Secretariat, op. 3, p. 243, Table of contents, no. 19: “T. Stalin. Zapis' besedy tov. Stalina s Sikorskim, 3.XII.41."

40. A. Ia. Vyshinskii, letter to Molotov on his travels with gen. Sikorski visiting Polish army units, December 10-15, 1941, AVP, Vyshinskii Secretariat, op. 2, p. 30, d. 10, p. 10, 1.104 (4). Sikorski's statement to Vyshinskii is confirmed by the general's statement to A. Eden in January 1943, that Stalin told him: "Lwo should again become part of Poland" and that Poland should annex East Prussia, see A. Polonsky, The Great Powers..., op. cit., no. 30: 97, note. 4. 
was to be restored within her 1939 frontiers. However, this statement was immediately contradicted by the qualification that the west Ukrainian and west Belorussian territories would revert to the USSR, except for regions with predominantly Polish populations. This could be done either by leaving Lvov (L'viv, Lwo to Poland, and transferring Belostok (BiaПystok) and Vilna (Vil'nius/Wilno) to the USSR, or vice versa, transfering Vilna and Belostok to Poland while leaving Lvov to the USSR. The document clearly indicates that Stalin recognized these cities as predominantly Polish. Furthermore, Polish territory was to be enlarged by annexing the western part of East Prussia. ${ }^{41}$ (In his conversations with Eden, Stalin went even further, speaking of a Polish western frontier on the Oder river. $)^{42}$ Thus, when Stalin tempted Sikorski with L'viv — probably in a private conversation at the banquet on December 4 - he saw it as one of the alternatives cited in the draft protocol to the Anglo-Soviet treaty. However, until the relevant Russian documents are accessible, we will not know for certain whether this is what Stalin intended to propose to Sikorski when the general returned to Moscow for another visit. (Sikorski was to return to Moscow after his tour of Polish army units, but fell ill with the flu and, true or not, this was the reason given for cancelling his projected second visit to the Soviet capital.)

The third place I worked in were the Archives of the President of the Russian Federation in the Tsentr Khraneniia Sovremennoi Dokumentatsii. As mentioned earlier, I had gone there originally in quest of the Stalin-Sikorski conversation of December 3, 1941, but was told this document was not there. However, the assistant director, a pleasant and efficient young woman, brought me a catalog of documents concerning Poland. This contained items on the deportations of Poles from former eastern Poland, with detailed instructions on how people were to be taken from their homes at dead of night to railway stations, loaded into cattle cars, where they were to go, etc. There were also documents on Katyn and the cover-up. I recognized many of the documents as published in Poland, and ordered xerox copies of those I had not seen before. In particular, I was intrigued by an instruction of July 3, 1940 sent by Stalin to an official named Grushko in the Lvov (L'viv) Obkom, with a copy to Nikita S. Khrushchev and another official named Burmistenko at the Central Committee, KP(b) Kiev. Stalin instructed the Lvov Obkom to stop job discrimination against Polish workmen, who had to claim they were Ukrainians in order to find work. Therefore, he ordered the Lvov Obkom to call a meeting of "the better sort of Polish people," hear their grievances, and then work out measures to improve relations with the Poles. ${ }^{43}$ I suspect that Wanda

41. See: Oleg Rzheshevskii, ed., "Vizit Edena v Moskvu v dekabre 1941 g. Peregovory s I. V. Stalinym i V. M. Molotovym," Novaia i noveishaia istoriia, 2 (1994): 85-102; Id.: War and diplomacy. The making of the grand alliance. Documents from Stalin's archives (Amsterdam, 1996) doc. no. 5, point 10, p. 23.

42. For a summary of the British version of the Eden-Stalin talks in Moscow, December 1941, see: S. M. Miner, Between Churchill ..., op. cit.: 186-193; the complete British text of the talks is in The Public Record Office, London, WP(42)8.

43. Stalin's telegram of July 3, 1940 to Lvov Obkom, TsKhSD, f. 89, op. 48, d. 6, 1. 1. 
Wasilewska may have drawn Stalin's attention to this problem. Whether she did or not, the instruction may indicate Stalin's interest in securing the loyalty of Polish workers in L'viv — which the draft Soviet protocol to the Anglo-Soviet treaty mentioned above recognized as a preponderantly Polish city. Thus, Stalin's instruction of July 3, 1940, may tie in with his support of Polish communist and left-wing intellectuals there, and may also be another indication that at this time he envisaged leaving the city in a postwar Poland controlled by Moscow. Furthermore, if Sikorski had agreed to frontier changes, he might have been welcome as the head of a Polish puppet government, for as mentioned earlier, in their talks with the Home Army leaders in February 1943, the PPR leaders proposed including him in a postwar Polish government. Indeed, there are indications that Sikorski envisaged ceding most of former eastern Poland to the USSR, ${ }^{44}$ but he could hardly have agreed to do so during the war without losing the support of the vast majority of Poles who perceived territorial cessions to the Soviet Union as the beginning of renewed Russian domination.

In conclusion, even though I did not find the type of documents that I was seeking, my stay in Moscow was well worthwhile. I found at least some documents that supplement the published sources on Stalin's actions towards Poland and thus throw more light on his policies. Also, I would like to say that I found the staff at all three archives to be most professional and helpful — and this despite their difficult material situation. However, it is clear that significant research on Soviet wartime foreign policy regarding Poland, and Soviet World War II policy in general, will become feasible only with the declassification of hitherto classified foreign policy documents for the period 1939-1945, and better still, 1933-1945, for this includes Soviet policy in the prewar years. The old series of Dokumenty vneshnei politiki SSSR, published from 1957 to 1977 , omitted 1939 - a decision made by V. M. Molotov. They consisted of carefully selected documents with ideological commentaries in the end notes. There has been a breakthrough with the publication of documents on 1939 in 1992, and on 1940-1941. However, large gaps still remain, particularly on the timing and internal justification of Stalin's decision to side with Hitler, as well as on the working out of the secret protocol to the pact of August 23, 1939.45 Other declassifications of war and postwar documents have been rather selective and sometimes inspired by political motives. For example, the Katyn documents held in sealed packets in the Presidential Archives, Kremlin, were declassified to support charges of criminal activity against the CPSU (b). Copies were given to President WaП'sa of Poland in October 1992, probably as a gesture of Russian good will to strengthen that country's links with Russia. The

44. On Sikorski's thoughts about ceding most of former eastern Poland to the USSR, as noted by his chief of Military Intelligence, colonel Leon Mitkiewicz, in January and March 1942, see: S. Meiklejohn Terry, Poland's place in Europe..., op. cit. : 128-130.

45. Dokumenty vneshnei politiki, XXII (1-2): 1939 god. (Moscow, 1992) and Dokumenty vneshnei politiki, XXIII (1; 2-1,2): 1940-1941 (Moscow, 1995; 1998). For a critical review of the documents for 1939, see: V. P. Safronov, Otechestvennaia istoriia, 3 (May-June 1995): 207- 210. 
same sets of criteria seem to apply to the gift of documents on the origins of the Korean war to the South Korean government in summer 1994 (Stalin's 1950 conversations with Kim Il Sung). Finally, though some Russian historians have, since 1989, obtained access to many hitherto classified documents and could publish them, Stalin's wartime thinking and goals are still the subject of controversy for lack of authoritative documentation.

British and U.S. documents provide many insights into the thinking and goals of Winston S. Churchill and Franklin D. Roosevelt on Poland with relation to the USSR, as well as their views and aims regarding the latter, Germany, Japan, and other states at different periods of the war. But today, as we near the sixtieth anniversary of the outbreak of World War II, historians wishing to use Russian archival sources in order to reconstruct Iosif V. Stalin's prewar, then wartime thinking and goals regarding Poland, the western powers, and other states - must do so mainly by extrapolation from actions recorded in documents written by Soviet officials, supplemented by his speeches and the Soviet press. The declassification of Central Committee and Politbiuro documents on foreign policy, as well as NKVD documents and more AVP materials for the years 1939-1945, is necessary to obtain a full picture of Stalin's thinking, and thus of Soviet foreign policy during this period. Let us hope that they will be declassified soon so that historians can stop guessing and proceed to fill a yawning gap in twentieth-century history.

The University of Kansas

Department of History

3001 Wescoe Hall

Lawrence KS 66045-2130

e-mail:annacien@eagle.cc.ukans.edu 